\title{
Study on Challenge and Countermeasures College English Faces from the Viewpoint of Curriculum Theory
}

\author{
Geng Bing \\ Jinan University, College of Foreign Studies, Guangzhou, 510632
}

Key words: curriculum theory, college English, college English course requirement

\begin{abstract}
This paper firstly summarizes that, since the issuing of College English Course Teaching Requirements in 2004, the student development demands, social development demands and science development demands have been changed, and the three main problems resulting from the demand change are as follows: 1) the polarization of freshmen's English proficiency is aggravated; 2) the shortage for the personnel with high English proficiency, international vision and Chinese vision is enlarged; 3) no attention to the effectiveness problem of the international language communication in the colleague English teaching gives rise to high input and low efficiency. Based on above problems, this paper puts forward three suggestions: 1) the English skill target should provide more options to the students; 2) provide first-class foreign education the excellent student, which is favorable for cultivating high-end talents; 3) provide teaching framework of the English to the teaching efficiency.

According to the curriculum theory, there are three bases for formulating and revising the course target: student development demands, social development demands and science development demands (Zhong Qiquan et al, 2008). With the change of the three demands, what challenge the college English faces? What countermeasures we should adopt? This paper explores the answers to these two questions from the viewpoint of the curriculum theory, which provides reference opinions for the further revision of "Course Requirements".
\end{abstract}

\section{Change of three demands and problems}

Student development demands

After entering into the $21^{\text {st }}$ century, the Ministry of Education has adopted a series of effective measures for the education training. It established national teacher education network alliance in 2006, and established national training plan project office in 2009. In 2010, China input RMB 0.55 billion to train 115 core teachers. In 2011, the Ministry of Education issued new training plan, and provided training to 10 million of middle school and primary school teachers based on classification, layers and posts. Through the implementation of New Curriculum Standard, the overall proficiency of the English in senior high schools in China was obviously improved. According to the informal investigation from the author, it turns out that, among the freshmen, the students that achieved above 8-level of the new curriculum accounted for 10-15\%. As our domestic foreign teachers and teaching resource distribution are not even. Besides, there is obvious regional difference, rural and urban difference in the English teaching quality over the country. The freshmen's foreign language proficiency presents polarization trend, and the difference of the student demands is greater than the previous one.

Social development demands

Recently, China has frequently communicated with foreign countries, while the shortage of the high-level foreign language talents has not been remedied. Instead, the gap is enlarged. China requires many talents that are familiar with applying the foreign language and law knowledge to negotiate with foreign countries and sign contracts; lawyers and judges that are familiar with the International Law, international trade act and WTO rules; senior tourism management talents that are familiar with the culture and language of the target countries. On July $8^{\text {th }}$, 2010, “Talent Shortage Hinders Chinese Enterprises to Go Out” publicized by China Youth News pointed out that, in China, there were only around 2,000 talents that could proficiently apply the foreign language 
and law knowledge to negotiate with the foreign countries and sign the contracts, and there are few lawyers that are familiar with International Law, International Trade Law and WTO rules. The article "Shortage of Talents Hinders Chinese Tourism Industry to Go Out" publicized by China News on May 27 $7^{\text {th }}, 2010$ pointed out that, although China had around 50,000 tourism enterprises, only 15 enterprises could get involved in the foreign business due to the shortage of senior tourism talents that are familiar with the foreign language.

Disciplinary development demands

English as a foreign language (EFL) teaching has more than one hundred of years. EFL is regarded as the study content for the native English speakers for a long time and the standard of measuring the failure or success. However, under the globalization background, the scope of the English application has been constantly expanded. The people using English to communication may be from Britain and America, but English is mostly adopted by non-native English speakers, such as Chinese and Swedish or Chinese and Thailand people. At present, the number of the non-native English speakers over the world has been far more than that of the native English speakers. English has already become a communication tool among the people from different countries (Alptekin 2010; Brumfit 2001; Ferguson 2010; Jenkins 2006; Seidlhofer 2001). Many scholars have put forward replacing EFL with "English as a lingua franca” (ELF), such as Seidlhofer (2011).

For a long time, our English teaching complies with the concept of EFL, and we basically regard the British English and American English as the standard to ass whether our domestic English learners achieve success or not, no matter the accuracy of the pronunciation, vocabulary and grammar, appropriateness of the pragmatics, so as to get closer to the standard of the native language. When studying and participating in the communication activities, people tend to ignore the effectiveness of the communication in ELF scene, and lay more emphasis on pursuing the perfectness of the language, but lack the tolerance to the language defect. They do not attach great importance to the thought expression. The students' and teachers' energy is not placed on the critical points, which gives rise to low learning efficiency.

\section{Pay attention to the problems and put forward countermeasures}

Provide more options to the students under the premise of requiring learning English

The foreign language proficiency of the freshmen presents polarization trend. The difference of the students' demands is enlarged. The author puts forward the countermeasures for solving the problems: required English course, selective skill target, selective course types; learn what are needed, and work according to the capability. The new teaching target does not require that the students' listening, speaking, reading, writing, and translating skills achieve the standard, and does not require students to become versatile English learners. The students can select different skill combination as own learning target, spend time and energy to study hard, and select courses that they prefer to learn, are interested in and have more confidence in from the "menu" courses. Course Requirement can stipulates that, if the student completes the two English skill courses and achieve proficiency degree and corresponding credits, this student can be confirmed to achieve the standard of this course. If the student has the capability to challenge his/her own potential and become a versatile English learner, we should encourage them to study more courses, and allow them to achieve single certificate one by one, but do not provide rigid requirements.

Regarding selective skill target, at present, Course Requirement divides the requirements for the students' English proficiency into three layers: ordinary requirement, relatively high requirement and higher requirement. The target of each layer includes five skills: listening, speaking, reading, writing and translating. The author holds that it is not ideal to require all university students to achieve the requirements of these five skills within 300 courses. The freshmen have great individual difference. Some are good at imitating, regarded as good talkers; some are good at listening, with rapid response and strong comprehensive; some have broad horizon, are interested in reading, and read fast; some think carefully, are good at writing. At present, the requirements for "five skills" without distinguishing are implemented. The same ruler is applied to assess all students. The consequence is that, many students may not pass the examination stipulated by the school or the 
country due to some weak skills, time consuming, energy consuming, and bad learning effect, and their confidence and enthusiasm will be seriously affected. During this unhappy learning process, due to the attention decentralization, the students' strong skills cannot be fully cultivated. What's worse, the students with weak foundation spend lots of time striving for passing CET-4 and CET-6 and neglecting own professional learning. In short, although the current college English teaching strives to cultivate "students with proficient foreign language skill", it always turns out that most students are not good at foreign language, and even the professional courses, which seems that the loss outweighs the gain for the country and individuals.

The author holds that, the root cause of Course Requirements showing higher requirements on the students lies in that, we do not correctly estimate the difficulty in learning English. At present, the students majoring in English from Grade 1 and 2 attach more importance to improving the listening, reading, writing and speaking skills. There are 14 lessons in a week, and around 1,008 hours in 2 years. Under such teaching condition with high intensity and high density, the teaching program requires the students to achieve balanced development in these four skills. However, the total teaching time of the college English in two years does not exceed 300 credit hours, less than 1/3 of the English major. To reach the spontaneous development of listening, speaking, reading, writing and translating skills, it is far from enough. In other words, the teaching time of our domestic college English is 288 credit hours, and that of the English courses in middle school is 864 credit hours, so that the total amount is 1,152 hours. Base on these limited teaching hours, only learning the English listening, speaking, and reading skills only can help the students achieve the primary and medium level (Level 2). However, some aspects that are not distinguished in Course Requirement are required to achieve "these five skills”. Such target is obviously so high.

Therefore, the author suggests endowing the students with the option for the college English skill target. The students can select 2 kinds or many kinds from these 5 skills as their own learning target according to their strengths, hobbies and future job expectation. As the number of the students that are not interested in learning is reduced, the teachers will have little difficulty in the classes, and the teaching effect and schedule can be naturally improved. The students also can achieve better cultivation. Some people may be worried that this method cannot help them achieve comprehensive skills, so that it cannot meet their work demands. We face two options. The first one is to require "versatile" skills. In fact, not all people can achieve it, and it weakens the students' self-confidence. On the other hand, apply the limited time to enable the students to focus on the skills from the selective parts. Although it is not comprehensive, the students can achieve successful experience when the parts they have learned achieve certain proficiency level, which lays solid foundation for the future study. Obviously, the second option is better than the first option. Course Requirement no long requires the students to be versatile, but it encourages them to become versatile. For the students that have good foundation, we have the responsibility to create conditions for them and provide convenience to them.

\section{Selective course types}

Based on "selective skill targets", it is necessary to provide different course types to the students. The author suggests that, based on taking English as a required course, Course Requirement stipulates the credits of the English courses should be acquired, but does not stipulate which English courses are required and should be changed to selective courses. The optional course system is composed of universal type and academic type. The universal module is divided into knowledge type and skill type. The knowledge course refers to the courses using English to learn international and Chinese culture knowledge. The skill course refers to the courses for cultivating the listening, speaking, reading, writing, interpreting and translating skills. The established courses are: listening and speaking classes, reading class, writing class, translating class, interpreting class, debate class, speech class, film and television class, etc. The academic module is divided into an ordinary academic type and special academic type. The former one shows offending major classification, such as academic writing. The latter one is related to specific majors, such as International Law, communication, accounting, etc., which seems as "professional English" which is mentioned 
frequently before.

\section{Provide first-class foreign language education to the freshmen with high English proficiency}

Many colleges apply the graded teaching and teach students in accordance of their aptitude, which is a good thing in fact. However, these schools always do as follows: allow the students who pass CET-4 to be exempted from the English. The reasons for this decision are as follows. Firstly, there are not enough college English teachers. To allow exemption can help the teachers to save some time to teach the students with weak English proficiency. Secondly, the currently established courses cannot meet the demands of the students with high level. It is better to make the students proceed with independent study than waste time in the classroom. It is hardly imagined that, these freshmen with high English proficiency are just the potential groups that are greatly needed by the country. If they can be exempted from English and are not cultivated, their English proficiency not only cannot be improved after graduation, but also will be reduced, which is a great pity. Not to make anyone fall behind, the students and teachers should cooperate together to realize the difficult "five skills", which is waste of teaching and learning. High-end resources are not completely developed. However, the low-end resources are excessively explored. The author believes this is the main cause for "high input and low output".

To meet the demands from the country towards the high-end foreign language talents, we should fully develop the potential of the freshmen with good English proficiency, and provide first-class foreign language education to them. A minority of colleges have established "top talent" classes, which is considered as a good mode. They employ first-class English teachers to these students, and carry out novel and flexible course setting, and some even use English to establish professional courses. The configuration mode of the resources from each college can suit measures to different conditions. But, the basic principle is to implement "teaching students in accordance of their aptitude".

Provide the teaching framework of the English interlingua

English Interlingua includes three sub-systems: language, culture, pragmatics (see Picture 1). Regarding the language sub-system, the teaching content should cover the native English, non-native English and local English (or China English). The native English is the common core of the English Interlingua, and the basis of the non-native English speakers to communicate. If such common basis does not exist, the function of the English Interlingua will not exist too. The purpose of learning non-native English is to improve the comprehension, especially listening to the non-native English with serious accent, such as Indian English, Singlish, etc. The local English refers to the special vocabulary and phrases for expressing the Chinese culture and scene, such as scientific outlook on development, well-being society, Chinese characteristic socialism, and other English expression methods. The teaching target of the language sub-system is to successfully communicate with others. In other words, we no longer take the accuracy, fluency and appropriateness of the language closer to the native language as the ideal target of the English teaching, but pursue the ability of successfully completing the actual tasks. The change of this target is to relieve the college English teaching from the traditional teaching. Besides, it is not necessary to spent time and energy to correct the mistakes that puzzle us for long time, such as Chinglish, no plural forms, no past tense, etc. The pronunciation and intonation regards making others understood as the target, and the vocabulary and grammar takes accurately conveying the meaning as the target. In short, it is necessary to regard the "act and succeed" as the ultimate assessment standard for the college English.

Similar to the language sub-system, the content of the culture subsystem of the English Interlingua covers the native English culture, non-native English culture and local culture. The culture refers to the great culture concept or universal culture, including philosophy thought, political system, history, geography, customs, etc. The traditional English teaching only attaches importance to the native language culture. More accurately, only learn the English and American culture. The non-native language culture is marginalized. The Chinese local culture is even rejected. This framework advocates learning the knowledge about these three kinds of culture. However, to 
learn the culture knowledge is not the target, as the culture knowledge is endless, but students' stay time in the school is short. Therefore, to learn three kinds of different culture is a mean. The ultimate target is to cultivate the cross-cultural communication capability, i.e. cultivating the sensitivity, tolerance, and flexibility towards the culture difference and its disposal.

The teaching content of the pragmatics subsystem includes universal general rules, native language rules and non-native language rules. The non-native language rules are endless. We cannot learn all rules, bear them in mind and abstract them from our brain if necessary. People cannot accurately predict the future communicators. Therefore, the learning rule is only a method. The key point is to cultivate students' ability to adapt themselves to the changing circumstances. For the academic language, it cultivates "ability of generating the proper strategies on line”.

It is important that these three subsystems cannot be mutually separated and separately operated. During the communication, the language, culture and pragmatics link with each other. From the viewpoint of the teaching, separate these three subsystems, so as to demonstrate their own teaching content and expected teaching results.

\section{Conclusion}

The foreign language education in China has gathered the wisdom and painstaking effort of many people, and achieved satisfactory result. The college English teaching is a systematic engineering and has impact on the whole process. Any reform we have pushed forward will get involved in the adjustment of many aspects, such as curriculum setting, teaching method, teaching assessment, teaching management, etc. The author hopes the related departments, more scholars and teachers break through the customary thought, face the reality, participate in the discussion, draw on the wisdom of the masses and strive to get countermeasures. Based on the extensive discussion and demonstration, it is feasible to try to establish experimental units in the qualified schools. After the reform helps people to achieve experience, it should continue the further promotion and then revise Course Requirement.

\section{References}

[1] Alptekin, C. 2010. Redefining multi competence for bilingualism and ELF[J]. Interna tional. Journal of Applied Linguistics. 20: 95-110.

[2] Brumfit,C.2001.Indivdual freedom in language Teaching: Helping Learners to Develop a Dialect of Their Own [M].Oxford: OUP.

[3] Ferguson ,G.2010.lssues in researching English as a lingua franca:A conceptual enquiry [J].International Journal of Applied Linguistics 19:117-135.

[4]Jenkins,J.2006.Current perspectives on teaching world English and English as a lingua franca [J].TESOL Quarterly 40:157-157. 